\title{
Carbon sources and trophic structure in an eelgrass Zostera marina bed, based on stable isotope and fatty acid analyses
}

\author{
Sybill Jaschinski*, Daniela C. Brepohl, Ulrich Sommer \\ IFM-GEOMAR Leibniz Institute of Marine Sciences, Düsternbrooker Weg 20, 24105 Kiel, Germany
}

\begin{abstract}
Multiple stable isotope and fatty acid analyses were applied to examine food web dynamics in an eelgrass Zostera marina L. system in the western Baltic Sea. Samples of eelgrass, epiphytic algae, sand microflora, red algae, phytoplankton and main consumer species were collected in June 2002. $\delta^{13} \mathrm{C}$ values of primary producers ranged from $-9.6 \%$ for eelgrass to the most depleted value of $-34.9 \%$ for the most abundant red alga, Delesseria sanguinea. Epiphyte $\delta^{13} \mathrm{C}(-11.3 \%)$ was close to the value for eelgrass, whereas sand microflora and phytoplankton showed intermediate values $\left(-20.0\right.$ and $-22.6 \%$, respectively). $\delta^{13} \mathrm{C}$ values of consumer species varied from $-12.2 \%$ in the gastropod Lacuna vincta to $-23.9 \%$ in the amphipod Amphitoe rubricata. Epiphytes, sand microflora and phytoplankton had relatively similar fatty acid signatures, indicating a dominance of diatoms. Fatty acid composition of the main consumers included the biomarker fatty acids for diatoms and red algae, whereas those for eelgrass were negligible. The stable isotope data in combination with the results of the fatty acid analysis strongly indicated that the food web in this eelgrass community was based on epiphytes, sand microflora and red algae. Additionally, the continuous distribution of $\delta^{15} \mathrm{~N}$ values implied a food web that was characterized by a large proportion of generalist feeders in every group of consumers and by a high degree of omnivory.
\end{abstract}

KEY WORDS: Food web structure $\cdot$ Seagrass $\cdot$ Epiphytes $\cdot$ Microphytobenthos $\cdot$ IsoSource

\section{INTRODUCTION}

Seagrass beds are widespread in shallow coastal waters and are considered as highly productive and diverse communities (Heck 1995, Lee et al. 2001). The eelgrass Zostera marina is a common species in subtidal habitats from the Arctic to the Mediterranean Sea. However, the high productivity of these systems is not due to angiosperm production alone, since epiphytic and sediment-associated microalgae are known to contribute significantly to total system production (Daehnick et al. 1992, Nelson \& Waaland 1997). Recent studies in seagrass ecosystems imply strong food web linkages between epiphytic and edaphic algae and consumers, whereas fresh seagrass leaves are assumed to be of minor importance (Lepoint et al. 2000, Moncreiff \& Sullivan 2001, Kang et al. 2003). Similar results have been found in saltmarsh and mangrove systems (Newell et al. 1995, Créach et al. 1997, Loneragan et al. 1997). The importance of algal material in comparison to vascular marine plants was confirmed in all studies, although saltmarsh grasses can contribute up to $50 \%$ to animal nutrition (Currin et al. 1995), and the contribution of detrital material is known to vary between seasons (Connolly et al. 2005).

The analysis of stable isotope ratios is a useful tool in determining the trophic pathways within marine food webs. Nevertheless, two complications can arise in the complex seagrass system. (1) The relatively large number of potential carbon sources in coastal areas often complicates the detection of the most important carbon sources. (2) Stable isotope analysis relies on distinct differences in stable isotope values of primary pro- 
ducer groups. The similarity of sources frequently prevents a clear distinction between several sources, especially in seagrasses and their associated epiphytes (Loneragan et al. 1997, Connolly et al. 2005). Recent studies have tried to solve these problems by applying complementary methods. Fatty acid analysis has been found to be a reliable method to trace food sources in aquatic food webs, since the conservative transfer of specific fatty acids has been proven in laboratory experiments (Lee et al. 1971). A number of 'indicator' fatty acids specific for algal groups like diatoms, dinoflagellates, or red algae can be used as biomarkers (Kayama et al. 1989, Viso \& Marty 1993), and the quantitative pattern of all fatty acids, the fatty acid signature, can provide additional information, especially at higher trophic levels (Iverson et al. 2002). Kharlamenko et al. (2001) combined stable isotope and fatty acid analyses to study an eelgrass food web in a semienclosed bay in Siberia. They concluded that eelgrass carbon, via the detritus pathway, played an important role in the studied eelgrass community. Similar conclusions were reached in a stable isotope study of an eelgrass bed in Alaska (McConnaughey \& McRoy 1979). In contrast, the view that eelgrass carbon plays a relative minor part in trophic pathways of seagrass communities was confirmed in 2 other studies, using the same technique (Stephenson et al. 1986, McClelland \& Valiela 1998).

We used a combination of stable isotope and fatty acid analyses in this study in order to determine the relevance of epiphytes and sediment-associated microalgae in an eelgrass community in the Baltic Sea.

\section{MATERIALS AND METHODS}

Study area. The research site was an eelgrass Zostera marina meadow adjacent to Falkenstein Beach in the inner Kiel Fjord, Germany $\left(54^{\circ} 21^{\prime} \mathrm{N}, 10^{\circ} 9^{\prime} \mathrm{E}\right)$. The Kiel Fjord is located in the Kiel Bight, a part of the western Baltic Sea. The eelgrass meadow extended over an area of 23 ha and was interrupted by small, unvegetated patches (Bobsien 2006). Due to the special hydrological situation in the Baltic Sea, salinity ranges between 10 and 20 PSU depending on discharge rates, prevailing winds and season. The astronomical tide range is negligible, but storm events can cause changes in water level. The studied eelgrass meadow extends from approximately 1.5 to $6 \mathrm{~m}$ depth. In June, eelgrass constituted $91 \%$ of the macrophyte biomass. The red algae grow attached to hard structures in the sediment. The sediment was sandy (grain size: 0.5 to $1 \mathrm{~mm}=42 \%,>1 \mathrm{~mm}=51 \%$ ). The content of organic matter was low $(<1 \%)$. Grain size and sediment organic content were analysed using standard methods. The sand microflora biomass in surface sedi-

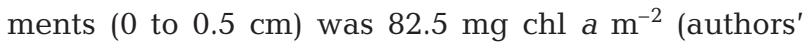
unpubl. data).

Sample collection. Samples of phytoplankton, eelgrass, attached epiphytes, red algae and the most common macrozoobenthic organisms and fish species were analysed in this study. Samples were collected at $3 \mathrm{~m}$ water depth on 24 June 2002. All samples of macrophytes and consumers were collected by dredging, placed in plastic containers with water from the collection site and transported to the laboratory for sorting and further processing. The phytoplankton sample was collected with a plankton net (mesh size $20 \mu \mathrm{m})$ by towing it 10 times from the bottom to surface and by combining the individual tows to 1 sample. Sand microflora, which consisted mostly of small prostrate diatoms in our study, is very difficult to sample directly. Some authors use composite muscle samples or the stomach content of a species known to feed exclusively on the assemblage of diatoms and bacteria in the sand as proxy (Newell et al. 1995, Moncreiff \& Sullivan 2001). Unfortunately such a consumer does not exist in the studied eelgrass community. Instead, we measured sand microflora indirectly as detritus-free sediment. Scuba divers took 15 sediment cores (1 cm inner diameter) within the eelgrass bed.

Sample processing. In the laboratory, the plant material (algae and eelgrass with epiphytes) was cleansed in $0.2 \mu \mathrm{m}$ filtered seawater in order to remove detrital fragments and attached animals. Epiphytes were carefully scraped from the eelgrass blades and transferred to small amounts of filtered seawater using a special plastic scraper and a scalpel. The phytoplankton sample was filtered by a $64 \mu \mathrm{m}$ sieve to remove zooplankton, faecal pellets and detritus. The cleaned epiphyte and phytoplankton samples were filtered on precombusted $\left(450^{\circ} \mathrm{C}, 24 \mathrm{~h}\right)$ Whatman $\mathrm{GF} / \mathrm{F}$ filters. The sediment cores were deep-frozen, the top $0.5 \mathrm{~cm}$ was cut off, and 5 at a time were pooled to yield a single sample. Visible detritus was manually removed, and the sediment samples were carefully rinsed with $0.2 \mu \mathrm{m}$ filtered seawater. Observations with a dissecting microscope before and after the cleaning procedure of epiphytes, phytoplankton and sediment showed the successful removal of unwanted material. The composition of primary producers was not affected. All samples for stable isotope analysis were dried to constant weight $\left(60^{\circ} \mathrm{C}, 24 \mathrm{~h}\right)$ and stored in a dessicator. All samples for fatty acid analysis were deep-frozen at $-80^{\circ} \mathrm{C}$.

All invertebrate species were kept alive overnight in filtered seawater to clear their guts. Muscle tissue was analysed for all fish species, Carcinus maenas and Mytilus edulis; the other invertebrate species were 
processed as whole organisms. Consumer and macrophyte samples for stable isotope analysis were dried to constant weight $\left(60^{\circ} \mathrm{C}, 48 \mathrm{~h}\right)$. The samples were ground with an agate mortar and pestle as fine as possible and then stored in airtight plastic vials. The shells of the gastropods were discarded as far as feasible before this procedure.

All fatty acid samples were deep-frozen at $-80^{\circ} \mathrm{C}$ until further processing.

Stable isotope analysis. Eelgrass and algal subsamples were transferred into tin cups. The consumer and sediment subsamples were transferred into silver cups, treated with $0.2 \mu \mathrm{l}$ of $10 \% \mathrm{HCl}$ to remove carbonates and then dried again. The use of $\mathrm{HCl}$ to remove nondietary carbon in tissue used for stable isotope analysis has been questioned, because the $\delta^{15} \mathrm{~N}$ values can also be influenced, but the elimination of carbonates is absolutely necessary for some organisms, especially small gastropods and crustaceans that could only be sampled by crushing their shell or carapace. Preliminary analyses showed no statistically significant differences of $\delta^{15} \mathrm{~N}$ values in acid or no-acid treatments in our samples (Jaschinski et al. 2008).

All consumer species were measured as individuals, except the small gastropod Rissoa membranacea, where 10 ind. were pooled in order to obtain sufficient material for analysis. All samples were combusted in a $\mathrm{CN}$-analyser (Fisons, 1500N) connected to a Finnigan Delta plus mass spectrometer. $\delta^{15} \mathrm{~N}$ and $\delta^{13} \mathrm{C}$ values were calculated as:

$$
\delta X(\%)=\left[\left(R_{\text {sample }} / R_{\text {standard }}\right)-1\right] \times 1000
$$

where $X$ is ${ }^{15} \mathrm{~N}$ or ${ }^{13} \mathrm{C}$ and $R$ is ${ }^{15} \mathrm{~N} /{ }^{14} \mathrm{~N}$ or ${ }^{13} \mathrm{C} /{ }^{12} \mathrm{C}$. Pure $\mathrm{N}_{2}$ and $\mathrm{CO}_{2}$ gas were used as primary standards and calibrated against IAEA reference standards (N1, N2, N3, NBS22 and USGS24). Acetanilide was used as an internal standard after every sixth sample. The overall analytical precision was $\pm 0.1 \%$ for $\delta^{15} \mathrm{~N}$ and $\delta^{13} \mathrm{C}$.

The model of Phillips \& Gregg (2003), that provides a range of feasible source mixtures, was used to determine the carbon sources:

$$
\begin{gathered}
\delta_{\mathrm{M}}=f_{\mathrm{A}} \delta_{\mathrm{A}}+f_{\mathrm{B}} \delta_{\mathrm{B}}+f_{\mathrm{C}} \delta_{\mathrm{C}} \\
1=f_{\mathrm{A}}+f_{\mathrm{B}}+f_{\mathrm{C}}
\end{gathered}
$$

where $f_{\mathrm{A}}, f_{\mathrm{B}}$ and $f_{\mathrm{C}}$ are the proportion of source isotopic signatures $\left(\delta_{\mathrm{A}}, \delta_{\mathrm{B}}\right.$ and $\left.\delta_{\mathrm{C}}\right)$, which coincide with the observed signature for the mixture $\left(\delta_{\mathrm{M}}\right)$. All possible combinations of primary producer contributions were analysed with an increment of $1 \%$. These predicted mixture signatures were compared with the measured values. If they were within a tolerance of $0.01 \%$, they were considered feasible solutions. We used only $\delta^{13} \mathrm{C}$ values in the modelling because of the sensitivity of the model to fractionation corrections (Connolly et al.
2005). The fractionation is much larger for ${ }^{15} \mathrm{~N}$ than for ${ }^{13} \mathrm{C}$ and can vary considerably between different species. We chose $0.5 \%$ as the average fractionation increase of ${ }^{13} \mathrm{C}$ for estuarine ecosystems (France \& Peters 1997). Calculations were carried out with IsoSource, a Visual Basic program, which is available for public use at www.epa.gov/wed/pages/models.htm. Epiphytes, the red alga Delesseria sanguinea and sand microflora were used as possible carbon sources for most consumers. We ran the model using phytoplankton, epiphytes and sand microflora as main autotroph carbon sources for the blue mussel Mytilus edulis, the common starfish Asterias rubens and the small sandeel Ammodytes tobianus. These species are known to depend on phytoplankton carbon (Castilla 1972, Wiedemeyer \& Schwamborn 1996, Muus \& Nielsen 1999).

Trophic levels were calculated according to the model of Hobson \& Welch (1992):

$$
\mathrm{TL}=1+\left(N_{\mathrm{m}}-N_{\mathrm{b}}\right) / \mathrm{TE}
$$

where TL is the trophic level of the consumer, $N_{\mathrm{m}}$ is the $\delta^{15} \mathrm{~N}$ value of the consumer, $N_{\mathrm{b}}$ is the average basis $\delta^{15} \mathrm{~N}$ value and TE the trophic enrichment factor in this system. A TL close to 2 is consistent with herbivorous nutrition, whereas a TL $\geq 3$ suggests a carnivorous diet. Averaging the $\delta^{15} \mathrm{~N}$ values for all primary producers, excluding phytoplankton, resulted in a mean of $7.0 \%$ as a baseline value to establish where TL 1 lies. The $\delta^{15} \mathrm{~N}$ values with the exception of carnivores ranged from 8.2 to $10.5 \%$, indicating for some consumers a trophic fractionation essentially lower than the mean value of $3 \%$ generally employed in aquatic systems. In general, trophic $\delta^{15} \mathrm{~N}$ enrichment of herbivores is highly variable (Vander Zanden \& Rasmussen 2001). Therefore, we averaged the $\delta{ }^{15} \mathrm{~N}$ values of herbivores (based on literature information) and calculated an average enrichment value $(1.5 \pm 0.1 \%)$. This fractionation was used to calculate trophic levels for potential herbivorous and omnivorous species. The trophic enrichment of carnivores is less variable. Provided that the average $\delta^{15} \mathrm{~N}$ value of primary consumers is used as a baseline, the resulting error is generally minor (Vander Zanden \& Rasmussen 2001). The trophic level of carnivores was determined using the mean $\delta^{15} \mathrm{~N}$ value of the same herbivore species as a baseline $(8.5 \pm$ $0.1 \%$ ) and $3 \%$ as the trophic enrichment factor (Vander Zanden \& Rasmussen 2001).

Fatty acid analysis. The macrophyte and consumer samples were freeze-dried for $48 \mathrm{~h}$, ground with an agate mortar and pestle and weighted. Macrophytes were processed as individuals, while consumers were pooled into 3 replicate samples containing 3 ind., with the exception of Rissoa membranacea, where $10 \mathrm{ind}$. were pooled to obtain sufficient material for analysis. 
Fatty acids were extracted, esterified and analysed on a gas chromatograph (GC) (Hewlett Packard 5890 Series II) following the method of Wiltshire et al. (2000) using the GC temperature settings of von Elert (2002). To quantify the fatty acid content an internal standard of heptadecanoic (17:0) and tricosanoic fatty (23:0) acid methyl esters was used.

Statistics. Differences between potential primary food sources (eelgrass, epiphytes, sand microflora, Delesseria sanguinea and phytoplankton) concerning stable isotopes were analysed by a 1-way ANOVA followed by a Student-Newman-Keul's test. Similar values prevent a clear distinction of food sources via the IsoSource model.

Calculations for fatty acid signatures were only performed for fatty acids represented with at least 1 value $>1 \%$. The similarity of total fatty acid composition of food sources and consumers was tested with non-metric multi-dimensional scaling (nMDS) using the program package PRIMER 5.0. Data were log-transformed before analysis.

\section{RESULTS}

\section{Stable isotope signature of primary producers}

The stable carbon isotope ratios of the studied primary producers in the eelgrass Zostera marina bed of Falkenstein showed a wide range of mean values from -9.6 to $-34.9 \%$ (Table 1 ). The quantitatively relevant primary producers eelgrass, epiphytes, sediment microflora, the red alga Delesseria sanguinea and phytoplankton showed significantly different values $(p<0.001)$. Eelgrass had a mean $\delta^{13} \mathrm{C}$ value of $-9.6 \%$, while that for its associated epiphytes (mainly prostate, stalked and tube-living diatoms) was

Table 1. $\delta^{13} \mathrm{C}$ and $\delta^{15} \mathrm{~N}$ values (mean $\pm \mathrm{SD}$ ) of primary producers in an eelgrass Zostera marina bed in the Kiel Bight, June 2002. Superscript letters show significant differences

\begin{tabular}{|lcccc|}
\hline Food source & $\mathrm{n}$ & $\delta^{13} \mathrm{C}(\%)$ & $\mathrm{n}$ & $\delta^{15} \mathrm{~N}(\%)$ \\
\hline Ahnfeltia plicata (Hudson) Fries & 3 & $-16.87 \pm 1.03$ & 3 & $10.30 \pm 0.93$ \\
Ceramium rubrum (Hudson) & 3 & $-17.43 \pm 0.15$ & 3 & $8.00 \pm 0.13$ \\
$\quad$ C. Argardh & & $-34.85 \pm 1.02^{\mathrm{a}}$ & 10 & $8.05 \pm 0.85^{\mathrm{a}}$ \\
$\begin{array}{l}\text { Delesseria sanguinea (Hudson) } \\
\text { Lamouroux }\end{array}$ & 10 & & 3 & $7.23 \pm 0.17$ \\
Polysiphonia fibrillosa (Dillwyn) & 3 & $-24.61 \pm 0.17$ & & \\
$\quad$ Sprengel & 10 & $-9.64 \pm 0.65^{\mathrm{b}}$ & 10 & $8.04 \pm 0.32^{\mathrm{a}}$ \\
Zostera marina Linnaeus & 10 & $-11.31 \pm 0.81^{\mathrm{c}}$ & 10 & $6.99 \pm 0.28^{\mathrm{b}}$ \\
Epiphytes on Z. marina & 3 & $-22.56 \pm 0.06^{\mathrm{d}}$ & 3 & $7.55 \pm 0.06^{\mathrm{b}}$ \\
Phytoplankton, 20 $\mu \mathrm{m}$ & 3 & $-20.04 \pm 0.23^{\mathrm{e}}$ & 3 & $6.00 \pm 0.42^{\mathrm{c}}$ \\
\hline Sediment microflora & & & &
\end{tabular}

$-11.3 \%$. Thus, the epiphytes were only slightly depleted compared to the mean $\delta^{13} \mathrm{C}$ value of eelgrass. The mean value for the sand microflora (mainly small, prostate diatoms) was $-20.0 \%$. Phytoplankton was isotopically lighter, showing a mean $\delta^{13} \mathrm{C}$ value of $-22.6 \%$. The dominant phytoplankton primary producer was the chain-forming diatom Dactylosolen fragilissima, a typical species of summer phytoplankton in the Kiel Bight. The red alga D. sanguinea had a substantially lighter mean $\delta^{13} \mathrm{C}$ value than all other primary producers $(-34.9 \%$ ). All other red algae had mean $\delta^{13} \mathrm{C}$ values ranging from -16.9 to $24.6 \%$, a range, which included the mean $\delta^{13} \mathrm{C}$ values of phytoplankton and sand microflora. However, these species were rather rare, and their contribution to system primary production was therefore considered negligible.

Stable nitrogen isotope ratios were similar (7.2 to $8.1 \%$ ) for eelgrass and all red algae, with the exception of Ahnfeltia plicata (10.3\%). The diatom-dominated samples (epiphytes, phytoplankton and sand microflora) had significantly lower mean $\delta^{15} \mathrm{~N}$ values than the macrophyte (eelgrass and Delesseria sanguinea) samples $(\mathrm{p}<0.001)$.

\section{Stable isotope signature of consumers}

Mean stable carbon isotope ratios of individual consumer species ranged from $-12.2 \%$ for the gastropod Lacuna vincta to $-23.9 \%$ for the amphipod Amphitoe rubricata (Table 2). The mean $\delta^{13} \mathrm{C}$ value for all consumers was $-18.6 \%$. The bivalve Mytilus edulis (the only important filter feeder in this eelgrass bed) had a $\delta^{13} \mathrm{C}$ value of $-21.8 \%$, which was only slightly enriched compared to the $\delta^{13} \mathrm{C}$ value for phytoplankton $(-22.6 \%)$. The IsoSource model based on phytoplankton, epiphytes and sand microflora suggested that $94 \%$ of the mussels' carbon is phytoplankton derived (Table 3). The common starfish Asterias rubens is considered to prey preferentially on $M$. edulis. However, its $\delta^{13} \mathrm{C}$ value $(-17.2 \%)$ indicated additional food sources. The contributions of phytoplankton, epiphytes and sand microflora were all about the same $(32,30$ and $38 \%$, respectively). Phytoplankton had the most likelihood of contributing to the sand eel Ammodytes tobianus $(68 \%)$ followed by sand microflora $(27 \%)$ and epiphytes (5\%).

The $\delta^{13} \mathrm{C}$ values for the 3 gastropods, Lacuna vincta $(-12.2 \%)$, Rissoa membranacea $(-14.4 \%)$ and Littorina lit- 
Table 2. $\delta^{13} \mathrm{C}$ and $\delta^{15} \mathrm{~N}$ values (mean $\pm \mathrm{SD}$ ) of consumers in an eelgrass Zostera marina bed in the Kiel Bight, June 2002

\begin{tabular}{|c|c|c|c|c|}
\hline Consumer & $\mathrm{n}$ & $\delta^{13} \mathrm{C}(\%)$ & $\mathrm{n}$ & $\delta^{15} \mathrm{~N}(\%)$ \\
\hline \multicolumn{5}{|l|}{ Annelida } \\
\hline Harmothoe imbricata (Linnaeus) & 5 & $-18.81 \pm 0.51$ & 5 & $11.88 \pm 0.14$ \\
\hline Nereis diversicolor O.F. Müller & 1 & -17.83 & 1 & 11.75 \\
\hline \multicolumn{5}{|l|}{ Bivalves and gastropods } \\
\hline Lacuna vincta Montagu & 3 & $-12.25 \pm 0.51$ & 3 & $9.23 \pm 0.25$ \\
\hline Littorina littorea (Linnaeus) & 10 & $-17.27 \pm 0.98$ & 10 & $9.50 \pm 0.20$ \\
\hline Mytilus edulis (Linnaeus) & 10 & $-21.81 \pm 0.41$ & 10 & $8.40 \pm 0.19$ \\
\hline Rissoa membranacea (J. Adams) & 3 & $-14.37 \pm 0.17$ & 3 & $8.21 \pm 0.06$ \\
\hline \multicolumn{5}{|l|}{ Crustacea } \\
\hline Amphitoe rubricata Montagu & 10 & $-23.88 \pm 0.72$ & 10 & $8.46 \pm 0.11$ \\
\hline Carcinus maenas (Linnaeus) & 5 & $-17.54 \pm 0.43$ & 5 & $12.66 \pm 0.58$ \\
\hline Corophium insidiosum Crawford & 5 & $-18.05 \pm 0.06$ & 5 & $8.78 \pm 0.06$ \\
\hline Crangon crangon (Linnaeus) & 10 & $-17.37 \pm 0.54$ & 10 & $11.63 \pm 0.23$ \\
\hline $\begin{array}{l}\text { Erichthonius difformis } \\
\text { Milne-Edwards }\end{array}$ & 7 & $-18.61 \pm 0.89$ & 7 & $8.24 \pm 0.23$ \\
\hline $\begin{array}{l}\text { Gammarus oceanicus (Segerstråle), } \\
10 \mathrm{~mm}\end{array}$ & 10 & $-19.01 \pm 0.38$ & 10 & $8.66 \pm 0.27$ \\
\hline $\begin{array}{l}\text { Gammarus oceanicus (Segerstråle), } \\
\text { 16-20 mm }\end{array}$ & 10 & $-23.80 \pm 0.74$ & 10 & $9.43 \pm 0.14$ \\
\hline Idotea baltica (Pallas), $8 \mathrm{~mm}$ & 10 & $-17.75 \pm 0.35$ & 10 & $8.92 \pm 0.25$ \\
\hline Idotea baltica (Pallas), $15 \mathrm{~mm}$ & 10 & $-17.08 \pm 0.48$ & 10 & $9.36 \pm 0.36$ \\
\hline Microdeutopus gryllotalpa A. Costa & 3 & $-18.13 \pm 0.69$ & 3 & $8.22 \pm 0.37$ \\
\hline Mysis mixta Lilljeborg & 5 & $-18.99 \pm 0.40$ & 5 & $11.67 \pm 0.28$ \\
\hline Palaemon adspersus Rathke & 10 & $-19.43 \pm 0.66$ & 10 & $10.49 \pm 0.18$ \\
\hline Praunus flexuosus (O.F. Müller) & 10 & $-19.47 \pm 0.22$ & 10 & $11.37 \pm 0.48$ \\
\hline \multicolumn{5}{|l|}{ Echinodermata } \\
\hline Asterias rubens Linnaeus & 5 & $-17.15 \pm 0.81$ & 5 & $11.61 \pm 0.77$ \\
\hline \multicolumn{5}{|l|}{ Fish } \\
\hline Ammodytes tobianus Linnaeus & 1 & -20.36 & 1 & 12.29 \\
\hline Gadus morhua Linnaeus & 1 & -19.03 & 1 & 14.41 \\
\hline Gasterosteus aculeatus Linnaeus & 5 & $-19.79 \pm 0.70$ & 5 & $13.92 \pm 0.19$ \\
\hline Gobiusculus flavescens (Fabricius) & 5 & $-20.06 \pm 0.18$ & 5 & $13.47 \pm 0.17$ \\
\hline Nerophis ophidion (Linnaeus) & 5 & $-18.21 \pm 0.77$ & 5 & $12.35 \pm 0.61$ \\
\hline Pholis gunnelus (Linnaeus) & 3 & $-19.90 \pm 0.05$ & 3 & $13.86 \pm 0.21$ \\
\hline Pomatoschistus minutus (Pallas) & 5 & $-17.29 \pm 0.81$ & 5 & $13.89 \pm 0.28$ \\
\hline Spinachia spinachia (Linnaeus) & 5 & $-17.96 \pm 0.21$ & 5 & $13.36 \pm 0.28$ \\
\hline Syngnathus typhle Linnaeus & 5 & $-18.29 \pm 0.89$ & 5 & $13.00 \pm 0.27$ \\
\hline Zoarces viviparus (Linnaeus) & 1 & -18.52 & 1 & 13.09 \\
\hline
\end{tabular}

tively). A narrow range of interspecific differences was found in the $\delta^{13} \mathrm{C}$ values for the 10 sampled fish species (maximum difference $=3 \%$ ), ranging from $-17.3 \%$ for the sand goby Potamoschistus minutes to $-20.1 \%$ for the three-spined stickleback Gasterosteus aculeatus. These values for fish taken as a group suggest a diet consisting, on average, of $33 \%$ epiphyte-, $47 \%$ sand microflora- and $20 \%$ D. sanguinea-derived carbon.

In Fig. $1, \delta^{13} \mathrm{C}$ values for all consumers and all primary carbon sources (eelgrass, epiphytes, phytoplankton, sediment microflora and the red alga Delesseria sanguinea) are plotted together. Herbivores had the greatest span in their $\delta^{13} \mathrm{C}$ values, whereas omnivores and carnivores exhibited a more narrow range. No significant difference in mean $\delta^{13} \mathrm{C}$ values was found between herbivores, omnivores and carnivores as grouped in Fig. 1 ( $\mathrm{p}=0.444)$.

Stable nitrogen isotope ratios for consumer species ranged from $8.2 \%$ for the gastropod Rissoa membranacea to $14.4 \%$ for the cod Gadus morhua (Table 2), and were indicative of the trophic level. The filter-feeding blue mussel Mytilus edulis $\left(\delta^{15} \mathrm{~N}=8.4 \%\right.$ occupied a very low trophic position, suggesting a largely herbivorous diet. The starfish Asterias rubens had a higher $\delta^{15} \mathrm{~N}$ value of $11.6 \%$ in accordance with its known carnivorous diet. The $\delta^{15} \mathrm{~N}$ values for the gastropods ranged from 8.2 to $9.5 \%$, corresponding to their herbivorous diet. The crustaceans torea $(-17.3 \%)$, suggested a decreasing dependence on epiphyte carbon $(90,70$ and $49 \%$, respectively) according to the IsoSource calculations. The crustaceans exhibited a wide range of $\delta^{13} \mathrm{C}$ values ranging from $-17.1 \%$ for the isopod Idotea baltica to $-23.9 \%$ for the amphipod Amphitoe rubricata, indicating a mixed diet including epiphytes, sediment microflora and red algae or species, which feed on these items (mean 36\% epiphyte-derived carbon, $44 \%$ sand microflora-derived carbon and 20\% Delesseria sanguinea-derived carbon). The carnivorous annelids Harmothoe imbricata and Nereis diversicolor had $\delta^{13} \mathrm{C}$ values of -18.8 and $-17.8 \%$, respectively, which suggested that they depend mainly on sand microflora for their ultimate carbon source (48 and 52\%, respecshowed a wide range of $\delta^{15} \mathrm{~N}$ values $(8.2 \%$ for the amphipod Microdeutopus gryllotalpa to $12.7 \%$ for the predator Carcinus maenas), in concordance with their trophic positions from herbivory to carnivory. The crustaceans can be divided into 3 groups: herbivorous amphipods mostly small $(\leq 1 \mathrm{~cm})$ and sessile, e.g. Corophium insidiosum, the omnivorous Gammarus oceanicus, Idotea baltica and Palaemon adspersus and the carnivorous shrimps Praunus flexuosus and Crangon crangon, the mysidacaean Mysis mixta and the green crab Carcinus maenas. All fish had $\delta^{15} \mathrm{~N}$ values corresponding to higher trophic positions (12.3 to $14.4 \%$ ). The top predator was juvenile cod Gadus morhua. $\delta^{15} \mathrm{~N}$ values of all consumers are shown in Fig. 2. No clear distinctions between trophic levels were apparent. 
Table 3. Results of the IsoSource model for consumers. Mean contributions of primary producers to consumer nutrition (parantheses: 1 to 99 percentile ranges). See Table 2 for full taxonomic names

\begin{tabular}{|c|c|c|c|c|}
\hline & $\begin{array}{l}\text { Plankton } \\
(\%)\end{array}$ & $\begin{array}{c}\text { Epiphytes } \\
(\%)\end{array}$ & $\begin{array}{c}\text { Sand } \\
\text { microflora (\%) }\end{array}$ & $\begin{array}{c}\text { Delesseria } \\
\text { sanguinea }(\%)\end{array}$ \\
\hline M. edulis & $94(90-97)$ & $1(0-2)$ & $6(1-10)$ & \\
\hline A. rubens & $32(1-60)$ & $30(22-39)$ & $38(1-77)$ & \\
\hline A. tobianus & $68(52-87)$ & $5(0-10)$ & $27(3-48)$ & \\
\hline H. imbricata & & $35(6-62)$ & $46(3-92)$ & $19(2-35)$ \\
\hline N. diversicolor & & $41(19-63)$ & $43(8-78)$ & $16(3-29)$ \\
\hline L. vincta & & $90(87-92)$ & $7(3-11)$ & $3(2-5)$ \\
\hline L. littorea & & $49(26-70)$ & $37(4-74)$ & $14(0-26)$ \\
\hline R. membranacea & & $70(61-83)$ & $23(3-38)$ & $7(1-14)$ \\
\hline A. rubricata & & $26(8-42)$ & $30(4-58)$ & $44(34-54)$ \\
\hline C. maenas & & $47(26-70)$ & $37(0-70)$ & $16(4-30)$ \\
\hline C. insidiosum & & $43(17-68)$ & $42(2-83)$ & $15(0-30)$ \\
\hline C. crangon & & $47(26-70)$ & $36(0-70)$ & $16(4-30)$ \\
\hline E. difformis & & $40(14-65)$ & $43(3-84)$ & $17(2-32)$ \\
\hline G. oceanicus, $10 \mathrm{~mm}$ & & $35(6-62)$ & $47(4-93)$ & $18(1-36)$ \\
\hline G. oceanicus, $16-20 \mathrm{~mm}$ & & $24(10-37)$ & $30(9-52)$ & $46(38-54)$ \\
\hline I. baltica, $8 \mathrm{~mm}$ & & $45(20-69)$ & $40(1-79)$ & $15(1-30)$ \\
\hline I. baltica, $15 \mathrm{~mm}$ & & $45(27-66)$ & $43(10-72)$ & $12(1-24)$ \\
\hline M. gryllotalpa & & $44(23-67)$ & $40(3-73)$ & $16(4-30)$ \\
\hline M. mixta & & $31(4-60)$ & $51(5-94)$ & $18(2-35)$ \\
\hline P. adspersus & & $30(4-60)$ & $49(2-91)$ & $21(5-38)$ \\
\hline$P$. flexuosus & & $29(7-51)$ & $51(16-86)$ & $20(7-33)$ \\
\hline G. morhua & & $33(5-61)$ & $44(0-89)$ & $23(6-39)$ \\
\hline G. aculeatus & & $27(1-57)$ & $48(1-90)$ & $25(9-42)$ \\
\hline G. flavescens & & $26(3-47)$ & $49(16-86)$ & $25(11-37)$ \\
\hline N. ophidion & & $37(9-65)$ & $45(1-90)$ & $18(1-34)$ \\
\hline P. gunnelus & & $25(2-46)$ & $51(18-88)$ & $24(10-36)$ \\
\hline$P$. minutus & & $39(15-64)$ & $46(7-85)$ & $15(0-29)$ \\
\hline S. spinachia & & $39(10-66)$ & $43(0-89)$ & $18(1-34)$ \\
\hline S. typhle & & $34(12-56)$ & $49(14-84)$ & $17(4-30)$ \\
\hline Z. viviparus & & $34(6-62)$ & $47(3-92)$ & $19(2-35)$ \\
\hline
\end{tabular}

fatty acids, including 20:5(n-3), and a higher quantity of 15:0, a fatty acid characteristic for anaerobic bacteria. Another biomarker fatty acid for aerobic heterotrophic bacteria, 18:1(n-7), occurred in small amounts in all potential primary food sources.

The red alga Delesseria sanguinea contained high quantities of 20:4(n-6) in accordance with data reported by Khotimchenko \& Vaskovsky (1990) for D. violacea.

The dominant fatty acid in all consumers was 16:0. Other saturated fatty acids were of no importance. The major monoenic fatty acids were in decreasing order of significance: 18:1(n-9), 16:1(n-7) and 18:1(n-7). Oleic acid 18:1(n-9) is a major fatty acid of most marine animal lipids (Dahl et al. 2003). The only relevant polyunsaturated fatty acid in all consumers was 20:5(n-3), which is characteristic for diatoms. The fatty acid signatures of all consumers alone and together with potential food sources were subjected to nMDS to evaluate similarities. The first nMDS plot (Fig. 3A) demonstrated that the primary food sources epiphytes, sand microflora, Delesseria sanguinea and phytoplankton were more similar to consumers than eelgrass concerning fatty acid composition. Eelgrass showed little similarity to other primary producers and the consumers. In a second nMDS plot (Fig. 3B) consumers were grouped into herbivorous gastropods (Rissoa membranacea, Lacuna vincta, Littorina littorea) and omnivorous crustaceans (Gammarus oceanicus and Idotea baltica), whereas the carnivorous green crab Carcinus maenas and polychaete Harmothoe imbricata showed little similarity to the other consumer species and each other.

\section{Biomarker fatty acids in dominant consumers}

The biomarker fatty acids used to identify food sources in this study are listed in Table 4. Biomarker fatty acids for eelgrass (Fig. 4A) were present in all consumer species, but only in insignificant amounts $(\leq 1.2 \%)$. In contrast, all consumers had high levels of the fatty acids 16:1(n-7) and 20:5(n-3) characteristic for 


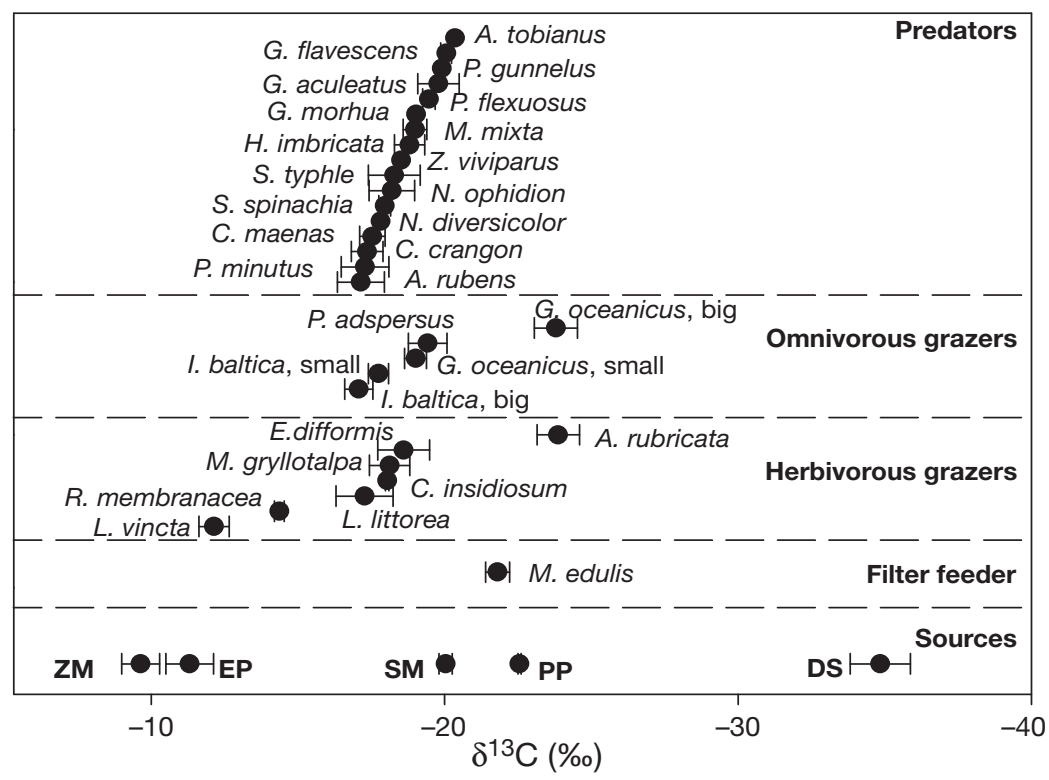

Fig. 1. $\delta^{13} \mathrm{C}$ values (mean $\pm \mathrm{SD}$ ) for consumers and the different, potential primary carbon sources, collected from an eelgrass Zostera marina bed in the Kiel Fjord, June 2002. ZM: Z. marina; EP: epiphytes; SM: sediment microflora; PP: phytoplankton; DS: Delesseria sanguinea. Animals were assigned to herbivore, omnivore and carnivore groups based on literature information. See Table 2 for full taxonomic names

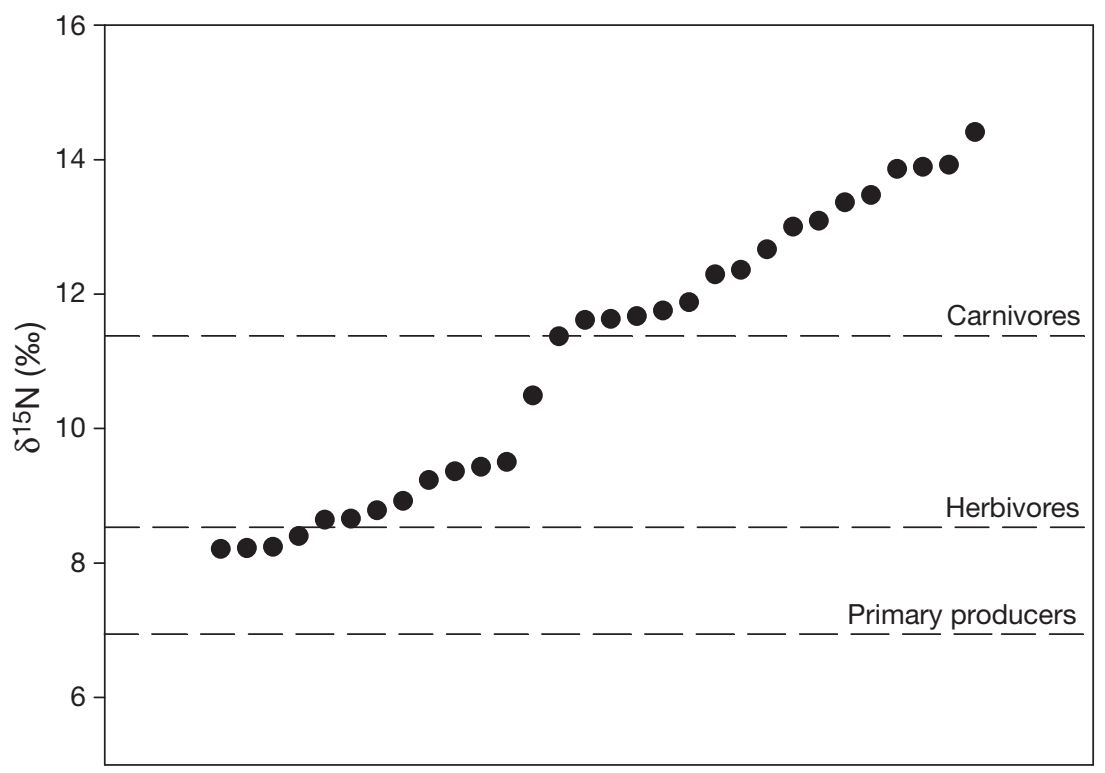

depleted---- $\delta^{15} \mathrm{~N}$---- enrinched

Fig. 2. $\delta^{15} \mathrm{~N}$ values for all consumer samples collected from an eelgrass Zostera marina bed in the Kiel Fjord, June 2002. Dashed lines indicate a mean $\delta^{15} \mathrm{~N}$ value for all primary producers, excluding phytoplankton, and the ideal herbivore and carnivore $\delta^{15} \mathrm{~N}$ values assuming a trophic fractionation of $1.5 \%$ for herbivores and $3 \%$ for carnivores

diatoms (Fig. 4B). The relatively low values of 16:1(n-7) in Carcinus maenas might be due to elongation of this fatty acid to $18: 1(n-7)$, which occurs in some marine animals (Dahl et al. 2003).
All consumers contained small amounts of 15:0, the biomarker for anaerobic bacteria $\left(-0.7 \%\right.$ of total $\mathrm{FA}_{\text {; }}$ Fig. 4C). However, significant amounts of 18:1(n-7), a biomarker for aerobic heterotrophic bacteria, were found in all animal species with the exception of Lacuna vincta. The high values of 18:1(n-7) in Carcinus maenas could be caused by the elongation of $16: 1(n-7)$ mentioned above. The fatty acid 20:4(n$6)$, characteristic for red algae, occurred in low amounts in all consumers (Fig. 4D); the highest amount was present in Gammarus oceanicus (4\% of total FA).

The primary fatty acid of phytoplankton (14:0) was merely found in low amounts in the studied consumer species (Fig. 4E). The unsaturated fatty acid 16:0, the dominant fatty acid in diatoms, was found in high amounts in all species with the exception of Carcinus maenas. Epiphytes and sand microflora contained relevant amounts of this fatty acid; however, the concentration in phytoplankton was significantly lower. The high content of 14:0 may be caused by the flagellates Emilia huxleyi, found in the phytoplankton sample. Prymnesiophyceae exhibit a high content of this fatty acid (Viso \& Marty 1993).

\section{DISCUSSION}

\section{Importance of epiphytes as carbon sources}

Stable carbon isotopic values and fatty acid composition of primary producers and consumers in the studied eelgrass Zostera marina bed strongly supported the assumption of a food web mainly based on epiphytes and sand microflora. Red algae and phytoplankton appear to be of minor importance in this system. The contribution of eelgrass seemed to be negligible.

Stable isotope studies are increasingly being used to determine the relative contributions of different sources of primary production to higher trophic levels in a multitude of aquatic ecosystems. The importance of seagrass, saltmarsh plants, or mangroves versus epiphytic or edaphic microalgae has been the subject of a long- 


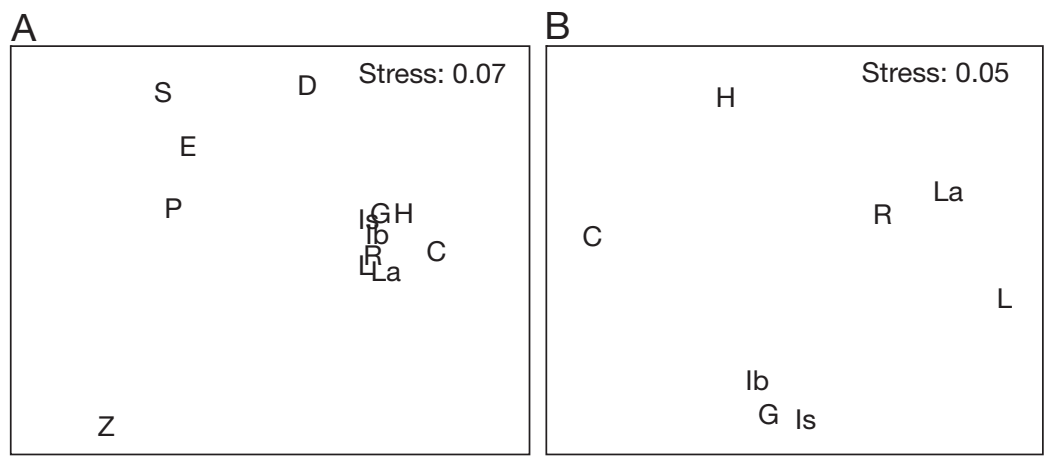

Fig. 3. Multi-dimensional scaling (MDS) plots of the total fatty acid composition of potential primary food sources and consumers. (A) Primary producers and consumers and (B) consumers alone. Stress $<0.05$ gives an excellent representation in a MDA analysis, while stress $<0.1$ gives a good representation. Z: Z. marina; E: epiphytes; S: sand microflora; D: D. sanguinea; P: phytoplankton; G: G. oceanicus; Is: I. baltica $8 \mathrm{~mm}$; Ib: I. baltica $15 \mathrm{~mm}$; R: R. membranacea; L: L. littorea; La: L. vincta; C: C. maenas; H: H. imbricata. See Table 2 for full taxonomic names
The contribution of phytoplankton carbon to higher trophic levels was assumed to be of minor importance in this eelgrass bed. The primary suspension feeder in this system, Mytilus edulis, contributed only a small fraction to total consumer biomass, and we found only small amounts of the fatty acid 14:0, characteristic for the sampled phytoplankton, in the other consumer species.

In accordance with the results of the fatty acid analyses, the contribution of primary producer carbon to higher trophic levels was calculated for epiphytes, sand microflora and red algae. According to the model of Phillips \& Gregg (2003) epiphytes and sand standing debate in shallow estuarine benthic ecosystems (Currin et al. 1995, Moncreiff \& Sullivan 2001, Connolly et al. 2005), and stable isotope studies can be a useful tool to answer this question. Nevertheless, the frequently occurring similarity of stable carbon isotope values of seagrasses and epiphytes can obscure the distinction between these 2 carbon sources (Loneragan et al. 1997, Connolly et al. 2005) as found in our study. To determine the contribution of these primary producers to higher trophic levels a combined approach is necessary.

The conservative transfer of fatty acids from primary producers to higher trophic levels was first demonstrated in laboratory experiments (Lee et al. 1971) and later in many food web studies in natural assemblages (Falk-Petersen et al. 2002, Dahl et al. 2003). The negligible amount of the main biomarker fatty acid for eelgrass 18:3(n-3) found in consumers strongly suggests that fresh eelgrass leaves are of minor importance for the carbon flow in this food web. A comparison of the fatty acid signature of primary producers and consumer species sampled in this study supports this assumption. Furthermore, we found no grazing scars on eelgrass blades. microflora were the major carbon sources, whereas red algae were of minor importance. No significant difference in $\delta^{13} \mathrm{C}$ values was found between herbivores, omnivores and carnivores as grouped in Fig. 1, although the contribution of epiphyte carbon to herbivores (mean 52\%) was higher than for the other 2 groups (34 and $35 \%$, respectively).

The most important herbivorous grazers in terms of consumer biomass were the gastropods Rissoa membranacea and Littorina littorea (Gohse-Reimann 2007). The gastropod Lacuna vincta was of no quantitative importance. The small gastropod $R$. membranacea is mainly found on eelgrass leaves and had $\delta^{13} \mathrm{C}$ values closest to those of epiphytes (70\% epiphyte-derived carbon). L. littorea appears to have a diet based more strongly on sand microflora (49\% epiphyte-derived carbon). High levels of 16:1(n-7) and 20:5(n-3) in both species confirmed the importance of diatoms in their diet (Viso \& Marty 1993, Desvilettes et al. 1997).

The dominant omnivorous crustacean in this eelgrass bed was Idotea baltica (Gohse-Reimann 2007), the most important benthic mesograzer in the Baltic Sea (Orav-Kotta \& Kotta 2004). This isopod is known for its wide range of food sources, including edaphic

Table 4. Biomarker fatty acids that were used in the present study to identify primary food sources in an eelgrass Zostera marina system in the Kiel Bight

\begin{tabular}{|lll|}
\hline Fatty acid & Biomarker for: & \multicolumn{1}{c|}{ Source } \\
\hline $16: 1(\mathrm{n}-7)$ & Diatoms & Viso \& Marty (1993), Desvilettes et al. (1997) \\
$20: 5(\mathrm{n}-3)$ & Diatoms & Viso \& Marty (1993), Desvilettes et al. (1997) \\
$18: 3(\mathrm{n}-3)$ & Zostera marina & Nichols et al. (1982), Khotimchenko (1990), Kharlamenko et al. (2001), present study \\
$18: 4(\mathrm{n}-3)$ & Zostera marina & Nichols et al. (1982), Khotimchenko (1990), Kharlamenko et al. (2001), present study \\
$20: 4(\mathrm{n}-6)$ & Red algae & Kayama et al. (1989), Khotimchenko (1990), present study \\
$15: 0$ & Anaerobic bacteria & Findlay et al. (1990), Desvilettes et al. (1997) \\
$18: 1(\mathrm{n}-7)$ & Aerobic bacteria & Findlay et al. (1990) \\
\hline
\end{tabular}



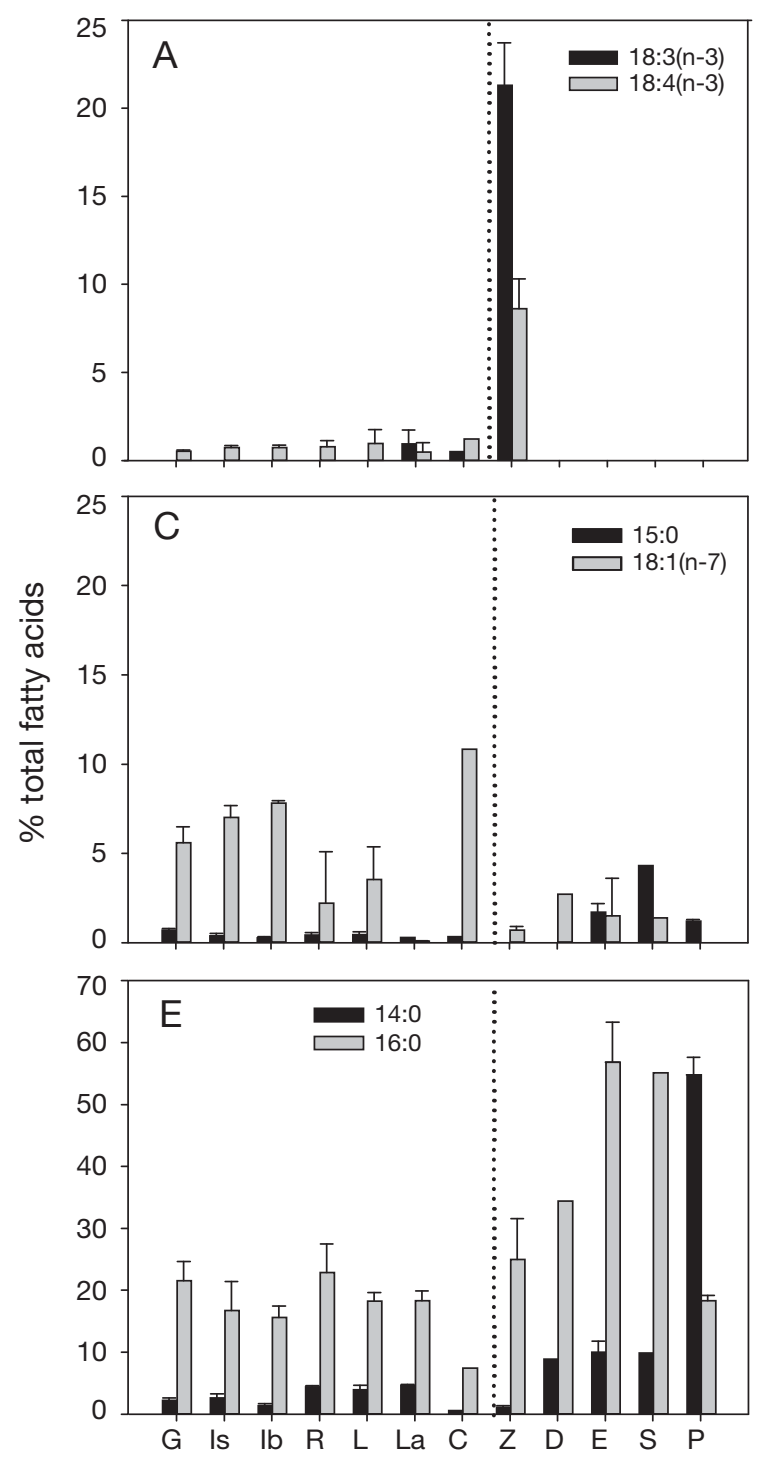

and epiphytic microalgae, filamentous algae, macroalgae, eelgrass and small invertebrate species (Franke \& Janke 1998, Orav-Kotta \& Kotta 2004). The importance of epiphytes and benthic diatoms for I. baltica was supported by the presumed high contribution of epiphyte and sand microflora carbon (mean 45 and $42 \%$, respectively) to their diet and the high amounts of the fatty acids 16:1(n-7) and 20:5(n-3), characteristic for diatoms. The biomarker fatty acids for eelgrass were present in negligible concentrations. The same held true for Gammarus oceanicus, but this amphipod contained lower amounts of 16:1(n-7) and 20:5(n-3) compared to I. baltica. Stable carbon isotope values also indicated a lesser importance of epiphyte-derived carbon for this species (mean contribution $30 \%$ ) and an increase in red alga-derived carbon (mean contribution $32 \%$ ). This result is in good accordance with a
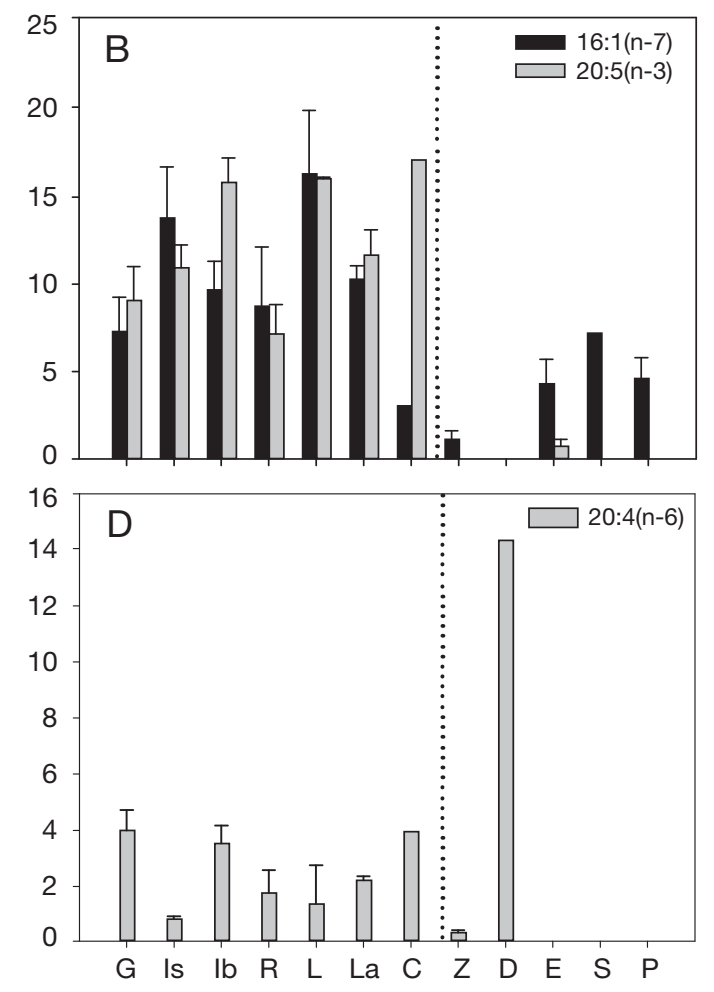

Fig. 4. Biomarker fatty acids in dominant animals and primary food sources: (A) eelgrass, (B) diatoms, (C) bacteria, (D) red algae and (E) phytoplankton. Data are mean \pm SD. The dotted lines separate primary producers and consumer species. Z: $Z$. marina; E: epiphytes; S: sand microflora; D: D. sanguinea; P: phytoplankton; G: G. oceanicus; Is: I. baltica $8 \mathrm{~mm}$; Ib: I. baltica $15 \mathrm{~mm}$; R: R. membranacea; L: L. littorea; La: L. vincta; C: C. maenas. See Table 2 for full taxonomic names

previously reported diminished grazing impact of amphipods on epiphytes compared to isopod mesograzers by Duffy et al. (2001). Both mesograzers are purported to be crucial links between primary production and higher trophic levels in seagrass systems (Edgar \& Shaw 1995).

The mean contribution of epiphyte carbon to the diet of the studied fish species was $33 \%$, whereas sediment microflora and Delesseria sanguinea contributed 47 and $20 \%$, respectively. This is in good accordance with gut analyses, which revealed a diet consisting mostly of isopods, amphipods and copepods in slightly varying amounts, planktonic organisms being of minor importance (Bobsien 2006).

Primary producer biomass was dominated by eelgrass in June (54 g AFDW [ash-free dry weight] $\mathrm{m}^{-2}$ ), followed by - in descending order-red algae $(4.9 \mathrm{~g}$ 
AFDW $\mathrm{m}^{-2}$ ), sand microflora (1.3 $\mathrm{g} \mathrm{AFDW} \mathrm{m}^{-2}$ ), epiphytes $\left(0.5 \mathrm{~g} \mathrm{AFDW} \mathrm{m}^{-2}\right)$ and phytoplankton $(0.3 \mathrm{~g}$ AFDW $\mathrm{m}^{-2}$ ) (Jaschinski \& Sommer 2008). In contrast, productivity rates measured in laboratory experiments under summer conditions showed that epiphytic algae (89.9 $\mathrm{mg} \mathrm{C} \mathrm{m}^{-2} \mathrm{~d}^{-1}$ ) had a higher primary production rates than eelgrass $\left(57.5 \mathrm{mg} \mathrm{C} \mathrm{m}^{-2} \mathrm{~d}^{-1}\right.$; S. Jaschinski \& U. Sommer unpubl. data). Previous studies have reported equal contributions of eelgrass and epiphytes to annual system carbon production (Borum \& WiumAndersen 1980, Thom 1990). Primary production of sand microflora ranged from 108 to $3312 \mathrm{mg} \mathrm{C} \mathrm{m}^{-2} \mathrm{~d}^{-1}$ in the sediments of Halodule wrightii beds in Mississippi Sound, where irradiance at the sediment surface was 80 to $900 \mu \mathrm{mol} \mathrm{m} \mathrm{m}^{-2} \mathrm{~s}^{-1}$ over a yearly cycle (Daehnick et al. 1992). If we assume their lowest production values characterise the summer rates of the sand microflora in this study, when irradiance reaching sediment is $100 \mu \mathrm{mol} \mathrm{m}{ }^{-2} \mathrm{~s}^{-1}$, benthic algal production (i.e. epiphyte and sand microflora) would be approximately 3 times greater than that of eelgrass.

Nutritional quality, digestibility and chemical defence of primary producers can additionally influence selective grazing. Benthic diatoms, dominating the epiphyton and sand microflora in this system, are considered as highly nutritious food sources (Klumpp et al. 1992, Créach et al. 1997), whereas eelgrass leaves were deficient in nitrogen compared to epiphytes ( $\mathrm{C}: \mathrm{N}=23$ and 12 , respectively). Furthermore, eelgrass contains lignin, which promotes structural rigidity in leaves but increases the proportion of indigestible material. In addition, deterrent phenolic compounds present in eelgrass are known to impede herbivory (Harrison 1982). Therefore, it can be assumed that eelgrass in the Kiel Bight primarily provides habitat and shelter for consumers, whereas food is mainly supplied indirectly by providing space for attached epiphytes or partially via the detritus pathway. The change of $\delta^{13} \mathrm{C}$ values during early decomposition of eelgrass is marginal, but the content of characteristic fatty acid is strongly decreased (Kharlamenko et al. 2001). The small amounts of 18:3(n-3) and 18:4(n-3), found in consumers in our study, may have originated from eelgrass detritus. The minor importance of eelgrass as a carbon source for sediment bacteria, found in 4 eelgrass beds in temperate regions (Boschker et al. 2000), supports our assumption that the role of eelgrass as a carbon source is negligible in the studied community. Kharlamenko et al. (2001), using the same techniques as in our study, concluded that eelgrass detritus contributed relevant amounts to consumer nutrition. Their study took place in a shallow, semi-enclosed bay with little water exchange. Eelgrass detritus may be more relevant under such hydrological conditions than at our more exposed study site.
Recent stable isotopic studies confirmed the importance of microscopic algae in seagrass food webs (Lepoint et al. 2000, Moncreiff \& Sullivan 2001, Connolly et al. 2005). A strong dependence on seagrass carbon was only found in a tropical food web for herbivorous fish species (Marguillier et al. 1997). The results of this study corroborate not only the importance of epiphytic algae in eelgrass systems, but also the significance of the frequently neglected sand microflora as found in other coastal ecosystems like tidal flats, saltmarsh and mangrove communities (Newell et al. 1995, Créach et al. 1997, Kang et al. 2003).

\section{Food web structure}

The suspension-feeding blue mussel Mytilus edulis occupies a low trophic position in the studied food web and its main carbon source was phytoplankton. Wiedemeyer \& Schwamborn (1996) likewise reported the predominance of phytoplankton as a carbon source for this mussel in the Kiel Fjord. Mussels are preyed upon by the starfish Asterias rubens ( $\mathrm{TL}=3.1$ ) and the green crab Carcinus maenas $(\mathrm{TL}=3.5)$. The starfish is mainly specialised as a predator on blue mussels; however, $\delta^{13} \mathrm{C}$ values suggested that starfish carbon was partially epiphyte-derived, possibly through preying on periwinkles. The green crab has a wider utilisation of food items, including small crustacean species and benthic annelids, which explains the higher trophic level of this predator.

Herbivores had the largest range of $\delta^{13} \mathrm{C}$ values, varying from the small gastropod Lacuna vincta $(-12.2 \%)$ to the amphipod Amphitoe rubricata $(-23.9 \%)$. L. vincta contained small amounts of eelgrass biomarker fatty acids and its $\delta^{13} \mathrm{C}$ value was close to that of epiphytes, indicating that its diet consisted mostly of epiphytes and to a smaller degree of eelgrass. This small gastropod is known to graze directly on the living tissue of macrophytes (Fredriksen 2003), and it can regulate epiphyte biomass in eelgrass communities (Nelson \& Waaland 1997). However, this species was not abundant at our study site and therefore of minor importance in this eelgrass system. A. rubricata was found living in tubes on the red algae Delesseria sanguinea. The mean $\delta^{13} \mathrm{C}$ value of this amphipod was closest to the value for $D$. sanguinea, suggesting that this red alga provided not only shelter, but also supplied a relevant part of its diet. A. rubricata is found only rarely at our study site. This species is more common in the red alga zone below the eelgrass meadow. Another small gastropod, Rissoa membranacea $(-14.4 \%)$, had a lower $\delta^{13} \mathrm{C}$ value than $L$. vincta. This species may be regarded as an important herbivorous epiphyte grazer in this system. In late summer $R$. membranacea can be found in huge numbers on the eel- 
grass leaves. All other herbivores showed intermediate $\delta^{13} \mathrm{C}$ values indicating a more general diet.

The observed continuous distribution of trophic positions supports the assumption that omnivory is a critical feature of this ecosystem. Therefore, our data agree with the hypothesis that consumer species in aquatic ecosystems make use of every possible trophic position in the food web (France et al. 1998). The lower $\delta^{15} \mathrm{~N}$ values of juvenile Idotea baltica and Gammarus oceanicus compared to adults (Table 2) may suggest an ontogenetic change in feeding behaviour. Such feeding plasticity was also found in fish species in this eelgrass system (Bobsien 2006).

All sampled fish species are considered carnivores. The two-spotted goby Gobiusculus flavescens, the sea stickleback Spinachia spinachia, the straightnose pipefish Nerophis ophidion and the broad-nosed pipefish Syngnathus typhle are the most common fish species in this eelgrass system (Bobsien 2006). The relatively small range in $\delta^{13} \mathrm{C}$ values supported the assumption that the studied fish species are generalists feeding on essentially the same crustacean prey species (Bobsien 2006). The dominant crustacean carnivore in this study was the green crab Carcinus maenas, another generalist species (Gohse-Reimann 2007). The other carnivorous crustacean species occurred only sporadically during the course of the year. The top predator in our study, juvenile cod Gadus morhua, which preyed in large schools in eelgrass beds in the Kiel Bight 30 yr ago (Worthmann 1975), are now greatly reduced in abundance. Only 2 ind. were caught in the course of the year.

\section{CONCLUSIONS}

This study emphasises the major importance of benthic microalgae (epiphytic and sediment-associated) for the carbon flux in eelgrass systems. The trophic contribution of the structuring macrophyte of this system (eelgrass Zostera marina) appeared to be minimal, and red algae and phytoplankton seemed to be of minor importance. The studied food web was characterised by a large proportion of generalist feeders in every group of consumers and by a high degree of omnivory. Overall, the combination of multiple stable isotope analyses and fatty acid analysis has been proven to be a useful tool in investigating 2 major approaches in the research of marine coastal ecosystems: the flux of carbon and food web structure.

Acknowledgements. We thank N. Aberle-Malzahn, S. Flöder, R. Karez and I. Peeken for helpful comments and T. Hansen for analysing the stable isotope samples. Financial support was provided by the German Research Foundation (So 145/20).

\section{LITERATURE CITED}

Bobsien I (2006) The role of small fish species in eelgrass food webs of the Baltic Sea. PhD dissertation, ChristianAlbrechts-University, Kiel

Borum J, Wium-Andersen S (1980) Biomass and production of epiphytes on eelgrass (Zostera marina L.) in the Øresund, Denmark. Ophelia (Suppl. 1):57-64

Boschker HTS, Wielemaker A, Schaub BEM, Holmer M (2000) Limited coupling of macrophyte production and bacterial carbon cycling in the sediment of Zostera spp. meadows. Mar Ecol Prog Ser 203:181-189

Castilla JC (1972) Responses of Asterias rubens to bivalve prey in a Y-maze. Mar Biol 12:222-228

Connolly RM, Hindell JS, Gorman D (2005) Seagrass and epiphytic algae support nutrition of a fisheries species, Sillago schomburgkii, in adjacent intertidal habitats. Mar Ecol Prog Ser 286:69-79

Créach V, Schricke MT, Bertru G, Mariotti A (1997) Stable isotopes and gut analyses to determine feeding relationships in saltmarsh macroconsumers. Estuar Coast Shelf Sci 44: 599-611

> Currin CA, Newell SY, Paerl HW (1995) The role of standing dead Spartina alterniflora and benthic microalgae in salt marsh food webs: considerations based on multiple stable isotope analysis. Mar Ecol Prog Ser 121:99-116

Daehnick AE, Sullivan MJ, Moncreiff CA (1992) Primary production of the sand microflora in seagrass beds of Mississippi Sound. Bot Mar 35:131-139

Dahl TM, Falk-Petersen S, Gabrielsen GW, Sargent JR, Hop H, Millar RM (2003) Lipids and stable isotopes in common eider, black-legged kittiwake and the northern fulmar: a trophic study from an Arctic fjord. Mar Ecol Prog Ser 256: 257-269

Desvilettes CH, Bourdier G, Amblard CH, Barth B (1997) Use of fatty acids for the assessment of zooplankton grazing on bacteria, protozoans and microalgae. Freshw Biol 38: $629-637$

Duffy JE, MacDonald KS, Rhode JM, Parker JD (2001) Grazer diversity, functional redundancy, and productivity in seagrass beds: an experimental test. Ecology 82:2417-2434

Edgar GJ, Shaw C (1995) The production and trophic ecology of shallow-water fish assemblages in southern Australia. III. General relationships between sediments, seagrasses, invertebrates and fishes. J Exp Mar Biol Ecol 194:107-131

Falk-Petersen S, Dahl TM, Scott CL, Sargent JR and others (2002) Lipid biomarkers and trophic linkages between ctenophores and copepods in Svalbard waters. Mar Ecol Prog Ser 227:187-194

Findlay RH, Trexler MB, Guckert JB, White DC (1990) Laboratory study of disturbance in marine sediments: response of a microbial community. Mar Ecol Prog Ser 62:121-133

France RL, Peters RH (1997) Ecosystem differences in the trophic enrichment of ${ }^{13} \mathrm{C}$ in aquatic food webs. Can J Fish Aquat Sci 54:1255-1258

France R, Chandler M, Peters R (1998) Mapping trophic continua of benthic foodwebs: body size- $\delta^{15} \mathrm{~N}$ relationships. Mar Ecol Prog Ser 174:301-306

> Franke HD, Janke M (1998) Mechanisms and consequences of intra- and interspecific interference competition in Idotea baltica (Pallas) and Idotea emarginata (Fabricius) (Crustacea: Isopoda): a laboratory study of possible proximate causes of habitat segregation. J Exp Mar Biol Ecol 227:1-21

Fredriksen S (2003) Food web studies in a Norwegian kelp forest based on stable isotope $\left(\delta^{13} \mathrm{C}\right.$ and $\left.\delta^{15} \mathrm{~N}\right)$ analysis. Mar Ecol Prog Ser 260:71-81 
Gohse-Reimann S (2007) Untersuchungen zur Ernährungsökologie benthischer Invertebraten im Makrophytensystem: ein marin-limnischer Ansatz. PhD dissertation, Christian-Albrechts-University, Kiel

Harrison PG (1982) Control of microbial growth and amphipod grazing by water-soluble compounds from leaves of Zostera marina. Mar Biol 67:225-230

Heck KL Jr (1995) Composition, abundance, biomass, and production of macrofauna in a New England estuary: comparison among eelgrass meadows and other nursery habitats. Estuaries 18:379-389

Hobson KA, Welch HE (1992) Determination of trophic relationships within a high Arctic marine food web using $\delta^{13} \mathrm{C}$ and $\delta^{15} \mathrm{~N}$ analysis. Mar Ecol Prog Ser 84:9-18

Iverson SJ, Frost KJ, Lang SLC (2002) Fat content and fatty acid composition of forage fish and invertebrates in Prince William Sound, Alaska: factors contributing to among and within species variability. Mar Ecol Prog Ser 241:161-181

Jaschinski S, Sommer U (2008) Functional diversity of mesograzers in an eelgrass-epiphyte system. Mar Biol (in press)

Jaschinski S, Hansen T, Sommer U (2008) Effects of acidification in multiple stable isotope analyses. Limnol Oceanogr 6:12-15

Kang CK, Kim JB, Lee KS, Kim JB, Lee PY, Hong JS (2003) Trophic importance of benthic microalgae to macrozoobenthos in coastal bay systems in Korea: dual stable $\mathrm{C}$ and $\mathrm{N}$ isotope analyses. Mar Ecol Prog Ser 259:79-92

Kayama M, Araki S, Sato S (1989) Lipids of marine plants. In: Ackman RG (ed) Marine biogenic lipids, fats, and oils, Vol 2. CRC Press, Boca Raton, p 3-48

Kharlamenko VI, Kiyashko SI, Imbs AB, Vyshkvartzev DI (2001) Identification of food sources of invertebrates from the seagrass Zostera marina community using carbon and sulfur stable isotope ratio and fatty acid analyses. Mar Ecol Prog Ser 220:103-117

Khotimchenko SV, Vaskovsky VE (1990) Distribution of $\mathrm{C}_{20}$ polyenoic fatty acids in red macrophytic algae. Bot Mar 33:525-528

Klumpp DW, Salita-Espinosa JS, Fortes MD (1992) The role of epiphytic periphyton and macroinvertebrate grazers in the trophic flux of a tropical seagrass community. Aquat Bot 43:327-349

Lee RF, Nevenzel JC, Paffenhoefer GA (1971) Importance of wax esters and other lipids in the marine food chain: phytoplankton and copepods. Mar Biol 9:99-108

Lee SY, Fong CW, Wu RSS (2001) The effect of structure of seagrass (Zostera japonica) canopy structure on associated fauna: a study using artificial seagrass units and sampling of natural beds. J Exp Mar Biol Ecol 259:23-50

Lepoint G, Nyssen F, Gobert S, Dauby P, Bouquegneau JM (2000) Relative impact of a seagrass bed and its adjacent epilithic algal community in consumer diets. Mar Biol 136:513-518

Loneragan NR, Bunn SE, Kellaway DM (1997) Are mangroves and seagrasses sources of organic carbon for penaeid prawns in a tropical Australian estuary? A multiple stableisotope study. Mar Biol 130:289-300

Marguillier S, van der Velde G, Dehairs F, Hemminga MA, Rajagopal S (1997) Trophic relationships in an interlinked mangrove-seagrass ecosystem as traced by $\delta^{13} \mathrm{C}$ and $\delta^{15} \mathrm{~N}$. Mar Ecol Prog Ser 151:115-121

McClelland JW, Valiela I (1998) Changes in food web structure under influence of increased antropogenic nitrogen inputs to estuaries. Mar Ecol Prog Ser 168:259-271

McConnaughey T, McRoy CP (1979) ${ }^{13} \mathrm{C}$ label identifies eelgrass (Zostera marina) carbon in an Alaskan estuarine food web. Mar Biol 53:263-269

Moncreiff CA, Sullivan MJ (2001) Trophic importance of epiphytic algae in subtropical seagrass beds: evidence from multiple stable isotope analyses. Mar Ecol Prog Ser 215: 93-106

Muus BJ, Nielsen JG (1999) Sea fish. Scandinavian Fishing Year Book, Hedehusene

Nelson TA, Waaland JR (1997) Seasonality of eelgrass, epiphyte, and grazer biomass and productivity in subtidal eelgrass meadows subjected to moderate tidal amplitude. Aquat Bot 56:51-74

Newell IE, Marshall N, Sasekumar A (1995) Relative importance of benthic microalgae, phytoplankton, and mangroves as sources for penaeid prawns and other invertebrates from Malaysia. Mar Biol 123:595-606

Nichols PD, Johns RB, Klumpp DW (1982) Study of foodchains in seagrass communities. 1. Lipid components of the seagrasses Posidonia australis and Heterozostera tasmanica as indicators of carbon source. Phytochemistry 21:1613-1621

Orav-Kotta H, Kotta J (2004) Food and habitat choice of the isopod Idotea baltica in the northeastern Baltic Sea. Hydrobiologia 514:79-85

Phillips DL, Gregg JW (2003) Source partitioning using stable isotopes: coping with too many sources. Oecologia 136: 261-269

Stephenson RL, Tan FC, Mann KH (1986) Use of stable carbon isotope ratios to compare plant material and potential consumers in a seagrass bed and a kelp bed in Nova Scotia, Canada. Mar Ecol Prog Ser 30:1-7

Thom RM (1990) Spatial and temporal patterns in plant standing stock and primary production in a temperate seagrass system. Bot Mar 33:497-510

Vander Zanden MJ, Rasmussen JB (2001) Variation in $\delta \delta^{15} \mathrm{~N}$ and $\delta^{13} \mathrm{C}$ trophic fractionation: implication for aquatic food web studies. Limnol Oceanogr 46:2061-2066

Viso AC, Marty JC (1993) Fatty acids from 28 marine microalgae. Phytochemistry 34:1521-1533

von Elert E (2002) Determination of limiting polyunsaturated fatty acids in Daphnia galeata using a new method to enrich food algae with single fatty acids. Limnol Oceanogr 47:1764-1773

Wiedemeyer WL, Schwamborn R (1996) Detritus derived from eelgrass and macroalgae as potential carbon source for Mytilus edulis in Kiel Fjord, Germany: a preliminary carbon isotopic study. Helgol Meersunters 50:409-413

Wiltshire KH, Boersma M, Möller A, Buhtz H (2000) Extraction of pigments and fatty acids from the green alga Scenedesmus obliquus (Chlorophyceae). Aquat Ecol 34: 119-126

Worthmann H (1975) Die Makrozoobenthos- und Fischbesiedlung in verschiedenen Flachwassergebieten der Kieler Bucht. Diploma thesis, Christian-Albrechts-University, Kiel

Submitted: May 25, 2006; Accepted: November 12, 2007 Proofs received from author(s): April 4, 2008
Editorial responsibility: Kenneth Heck, Dauphin Island, Alabama, USA 